Article

\title{
Synergism of Pt nanoparticles and iron oxide support for chemoselective hydrogenation of nitroarenes under mild conditions
}

\author{
Pei Jing a, Tao Gan a, Hui Qi b, Bin Zheng a, Xuefeng Chu c, Guiyang Yu a, Wenfu Yan a, Yongcun Zou a, \\ Wenxiang Zhang a,*, Gang Liu a,\# \\ a State Key Laboratory of Inorganic Synthesis and Preparative Chemistry, College of Chemistry, Jilin University, Changchun 130012, Jilin, China \\ b The Second Hospital of Jilin University, Changchun 130041, Jilin, China \\ c Provincial Key Laboratory of Architectural Electricity \& Comprehensive Energy Saving, School of Electrical and Electronic Information Engineering, Jilin \\ Jianzhu University, Changchun 130118, Jilin, China
}

\section{A R T I C L E I N F O}

\section{Article history:}

Received 18 December 2018

Accepted 20 December 2018

Published 5 February 2019

\section{Keywords:}

Supported Pt catalyst

Iron oxide

Nitroarene hydrogenation

Chemoselectivity

Noble metal catalysis

\begin{abstract}
A B S T R A C T
An efficient and low-cost supported Pt catalyst for hydrogenation of niroarenes was prepared with colloid Pt precursors and $\alpha-\mathrm{Fe}_{2} \mathrm{O}_{3}$ as a support. The catalyst with Pt content as low as $0.2 \mathrm{wt} \%$ exhibits high activities, chemoselectivities and stability in the hydrogenation of nitrobenzene and a variety of niroarenes. The conversion of nitrobenzene can reach 3170 molconv $^{-1}$ molpt $^{-1}$ under mild conditions $\left(30^{\circ} \mathrm{C}, 5 \mathrm{bar}\right)$, which is much higher than that of commercial Pt/C catalyst and many reported catalysts under similar reaction conditions. The spatial separation of the active sites for $\mathrm{H}_{2}$ dissociation and hydrogenation should be responsible for the high chemoselectivity, which decreases the contact possibility between the reducible groups of nitroarenes and Pt nanoparticles. The unique surface properties of $\alpha-\mathrm{Fe}_{2} \mathrm{O}_{3}$ play an important role in the reaction process. It provides active sites for hydrogen spillover and reactant adsorption, and ultimately completes the hydrogenation of the nitro group on the catalyst surface.
\end{abstract}

(C) 2019, Dalian Institute of Chemical Physics, Chinese Academy of Sciences. Published by Elsevier B.V. All rights reserved.

\section{Introduction}

Pt-group metals supported on oxides or carbon are of great importance in many industrial chemical processes as heterogeneous catalysts [1-3]. They usually exhibit high efficiency in both oxidation and reduction reactions [4-7]. However, large scale application of Pt-based catalysts is still limited by their high cost [8-11]. Moreover, active Pt sites cannot discriminate the differences of functional groups, causing a low catalytic selectivity [12-14]. Take the hydrogenation of nitroarenes as an example, nitro groups and other reducible groups (e.g., $\mathrm{C}=\mathrm{C}$, $\mathrm{C}=\mathrm{O}, \mathrm{X}$, etc.) can be simultaneously hydrogenated over Pt metal active sites [15-18]. Some solutions for improving the selectivity include adding metal salts or organic compounds as additives, or loading a less active component (e.g., $\mathrm{Au}, \mathrm{Ag}$, etc.) [19-23]. The role of additives is to avoid the accumulation of hazardous aromatic hydroxylamines or lower the flat adsorption of nitroarenes with the benzene ring to decrease a simultaneous exposure of the reducible groups toward the active sites. However, most of them are at the cost of catalytic activity,

\footnotetext{
*Corresponding author. Tel: +86-431-85155390; Fax: +86-431-88499140; E-mail: zhwenx@jlu.edu.cn \# Corresponding author. Tel: +86-431-85155390; Fax: +86-431-88499140; E-mail: lgang@jlu.edu.cn This work was supported by the National Natural Science Foundation of China $(21473073,21473074)$, "13th Five-Year" Science and Technology Research of the Education Department of Jilin Province (2016403), the Development Project of Science and Technology of Jilin Province (20170101171JC, 20180201068SF), and the Open Project of State Key Laboratory of Inorganic Synthesis and Preparative Chemistry (201703). DOI: S1872-2067(19)63276-6 | http://www.sciencedirect.com/science/journal/18722067 | Chin. J. Catal., Vol. 40, No. 2, February 2019
} 
and additional metal salts also face with the post-processing and new environmental problems.

Recent research shows that rational design of Pt-group centers and/or proper regulating the environment around Pt sites could obtain highly chemoselective catalysts for hydrogenation of nitroarenes [24-29]. For example, Zhang's group [24] reported that the catalyst with single-atom and pseudo-single-atom $\mathrm{Pt}$ supported on $\mathrm{FeO}_{\mathrm{x}}$ exhibits high activity and chemoselectivity for hydrogenation of functional nitroarenes. Corma et al. [25] showed that the chemoselectivity can be significantly improved by generating nanosized Pt with special exposed crystal faces on the surface of $\mathrm{T}^{\mathrm{TiO}} \mathrm{O}_{2}$ support. $\mathrm{Qu}$ and his coworkers [26] used porous $\mathrm{CeO}_{2}$ nanorods supported sub-nanometric Pd clusters as catalysts to improve chemoselectivity. However, practical applications of these catalysts still face great challenges due to the dependence of activity on the amount of Pt loading [28]. Reducing the Pt sites within the catalysts has a significantly negative effect on the catalytic activity. Moreover, the aggregation of Pt nanoparticles and stability of the oxide supports under strong reduction atmosphere also deserve concern.

In this work, we attempt to carry out the strategy of spatial separating the active sites to develop low cost and highly efficient catalysts for chemoselective hydrogenation of nitroarenes. It is expected to introduce the participation of oxide supports to enhance the utilization efficiency of Pt sites. This strategy is mainly based on the $\mathrm{H}_{2}$-spillover mechanism. The challenges for realizing this strategy include the efficiency of $\mathrm{H}_{2}$ dissociation over Pt centers, and the capacity of $\mathrm{H}$ diffusion and reactants adsorption over oxide supports [30-32]. More important is the synergism of these performances over Pt and oxide supports. Therefore, the fabrication of Pt sites and choosing well-matched oxides supports are the key factors for this strategy.

For achieving above goals, a colloid method is adopted to prepare Pt active centers, which has been proved in our previous work that this method could effectively control the sizes and the dispersion states of Pt particles [4,33]. Considering the strong electron-withdrawing properties of nitro groups, several metal oxides with Lewis-basic sites are screened as catalyst supports, including $\mathrm{Fe}_{2} \mathrm{O}_{3}, \mathrm{CeO}_{2}, \mathrm{Al}_{2} \mathrm{O}_{3} \mathrm{MgO}$ and $\mathrm{TiO}_{2}$. They could generally provide large number of electron-rich sites to interact with nitro groups [34,35]. Interestingly, $\mathrm{Pt} / \mathrm{Fe}_{2} \mathrm{O}_{3}$ with Pt-loading amount as low as 0.2 wt \% exhibits high catalytic activities and chemoselectivities in the hydrogenation of a variety of nitroarenes. It should be noted that the catalytic tests are carried out under quite mild reaction conditions $\left(30^{\circ} \mathrm{C}, 5\right.$ bar $\mathrm{H}_{2}$ ). Besides, both the Pt nanoparticles and $\mathrm{Fe}_{2} \mathrm{O}_{3}$ support exhibit a high stability under the strong reduction atmosphere. The highly efficient $\mathrm{H}_{2}$ dissociation over $\mathrm{Pt}$ nanoparticles $\left(\mathrm{Pt}^{0}\right)$, and the capacity of $\mathrm{H}$ diffusion and reactant adsorption over $\alpha$-phase $\mathrm{Fe}_{2} \mathrm{O}_{3}$ should be co-responsible for the excellent performance of $\mathrm{Pt} / \mathrm{Fe}_{2} \mathrm{O}_{3}$ catalysts.

\section{Experimental}

\subsection{Materials}

Hexachloroplatinic(IV) acid hexahydrate, $\mathrm{Fe}\left(\mathrm{NO}_{3}\right)_{3} \cdot 9 \mathrm{H}_{2} \mathrm{O}$, $\mathrm{Ce}\left(\mathrm{NO}_{3}\right)_{3} \cdot 6 \mathrm{H}_{2} \mathrm{O}$ and sodium carbonate were purchased from Sinopharm Chemical Reagent Co., Ltd. Sodium hydroxide was obtained from Beijing Chemical Work. Titania P25 ( $\left.\mathrm{TiO}_{2}\right)$ was purchased from Evonik Degussa (ca. $50 \mathrm{~m}^{2} / \mathrm{g}$, anatase ca. $80 \%$ and rutile ca. 20\%). Magnesium oxide (MgO) was obtained from Tianjin Fuchen Chemical Reagents Factory. Alumina oxides $\left(\gamma-\mathrm{Al}_{2} \mathrm{O}_{3}\right)$ were purchased from Longkou Chemical Paking Co., Ltd. All chemical reagents used in the experiment were of commercially available analytical grade, which were used without further purification.

\subsection{Preparation of oxide supports and Pt colloids}

The precursor of the $\mathrm{Fe}_{2} \mathrm{O}_{3}$ support was prepared via a precipitation reaction of an aqueous solution of $\mathrm{Fe}\left(\mathrm{NO}_{3}\right)_{3} \cdot 9 \mathrm{H}_{2} \mathrm{O}$ with sodium carbonate. In a typical preparation, a $\mathrm{Na}_{2} \mathrm{CO}_{3}$ aqueous solution was obtained by dissolving $23 \mathrm{~g}$ of $\mathrm{Na}_{2} \mathrm{CO}_{3}$ in $100 \mathrm{~mL}$ of water. $100 \mathrm{~mL}$ of an aqueous solution containing 56 g of $\mathrm{Fe}\left(\mathrm{NO}_{3}\right)_{3} \cdot 9 \mathrm{H}_{2} \mathrm{O}$ was added dropwise into above solution. Then, additional aqueous solution of $\mathrm{Na}_{2} \mathrm{CO}_{3}(0.1 \mathrm{~mol} / \mathrm{L})$ was added into the mixture until the $\mathrm{pH}$ value reached 9.0. After aging for $2 \mathrm{~h}$, the precursor was collected by filtration and washing with distilled water. Finally, the $\mathrm{Fe}_{2} \mathrm{O}_{3}$ support was obtained by calcining the precursor at $500{ }^{\circ} \mathrm{C}$ for $3 \mathrm{~h}$. $\mathrm{CeO}_{2}$ was prepared by thermal treating $\mathrm{Ce}\left(\mathrm{NO}_{3}\right)_{3}{ }^{\circ} 6 \mathrm{H}_{2} \mathrm{O}$ at $350^{\circ} \mathrm{C}$ for $4 \mathrm{~h}$.

Platinum colloids were prepared by a polyol reduction method which was reported in our previous work [4,33]. Typically, $13.5 \mathrm{~mL}$ glycol solution of sodium hydroxide $(0.34 \mathrm{~mol} / \mathrm{L})$ and $30 \mathrm{~mL}$ glycol solution of $\mathrm{H}_{2} \mathrm{PtCl}_{6} \cdot 6 \mathrm{H}_{2} \mathrm{O}\left(8.5 \times 10^{-4} \mathrm{~mol} / \mathrm{L}\right)$ were mixed under vigorous stirring for $20 \mathrm{~min}$, and then heated at $140{ }^{\circ} \mathrm{C}$ for $30 \mathrm{~min}$ under $\mathrm{N}_{2}$ flow.

\subsection{Preparation of supported Pt catalysts}

All the oxides-supported Pt catalysts were prepared using a colloidal deposition method. Taking $\mathrm{Pt} / \mathrm{Fe}_{2} \mathrm{O}_{3}$ catalyst as an example, a certain amount of $\mathrm{Fe}_{2} \mathrm{O}_{3}$ was added to the Pt colloids. After stirring for about $2 \mathrm{~h}$ at room temperature, the mixture was heated at $80{ }^{\circ} \mathrm{C}$ for $12 \mathrm{~h}$. Then, the resulting mixture was filtered and washed several times with distilled water and dried at $100{ }^{\circ} \mathrm{C}$ overnight. Before characterizations and activity tests, the obtained solid was calcined in $20 \% \mathrm{O}_{2} / \mathrm{Ar}$ at $200{ }^{\circ} \mathrm{C}$ for $2 \mathrm{~h}$. The loading amount of $\mathrm{Pt}$ in $\mathrm{Pt} / \mathrm{Fe}_{2} \mathrm{O}_{3}$ was tuned by the content of Pt colloids in the mixture, and finally identified with an inductively coupled plasma atomic emission spectrometer (ICP). According to the ICP results, the samples were denoted as $0.1 \mathrm{wt} \% \mathrm{Pt} / \mathrm{Fe}_{2} \mathrm{O}_{3}, 0.2 \mathrm{wt} \% \mathrm{Pt} / \mathrm{Fe}_{2} \mathrm{O}_{3}$ and $0.5 \mathrm{wt} \%$ $\mathrm{Pt} / \mathrm{Fe}_{2} \mathrm{O}_{3}$. The preparation of other oxides-supported Pt catalysts also used the above colloidal deposition method. The loading amount of Pt was identified by ICP and shown in Table 1.

\subsection{Characterizations}

Powder X-ray diffraction (XRD) patterns were recorded with a Rigaku X-ray diffractometer using $\mathrm{Cu} K_{\alpha}$ radiation $(\lambda=$ 
Table 1

Hydrogenation of nitrobenzene over different supported Pt catalysts a

\begin{tabular}{|c|c|c|c|c|c|c|}
\hline \multirow{2}{*}{ Entry } & \multirow{2}{*}{ Catalyst } & \multirow{2}{*}{$\begin{array}{l}\text { Pt content }{ }^{b} \\
\text { (wt } \%)\end{array}$} & \multicolumn{3}{|c|}{ Conv. (\%) } & \multirow{2}{*}{$\begin{array}{l}\text { Sel. } \\
(\%)\end{array}$} \\
\hline & & & Cycle 1 & Cycle 2 & Cycle 3 & \\
\hline 1 & None & 0 & 0.9 & - & - & - \\
\hline 2 & $\mathrm{Fe}_{2} \mathrm{O}_{3}$ & 0 & 1.2 & - & - & - \\
\hline 3 & $\mathrm{Pt} / \mathrm{Fe}_{2} \mathrm{O}_{3}$ & 0.2 & 100 & 99.7 & 99.2 & $>99$ \\
\hline 4 & $\mathrm{Pt} / \mathrm{CeO}_{2}$ & 0.4 & 100 & 85.2 & 35.3 & $>99$ \\
\hline 5 & $\mathrm{Pt} / \mathrm{MgO}$ & 0.3 & 88.5 & - & - & $>99$ \\
\hline 6 & $\mathrm{Pt} / \mathrm{Al}_{2} \mathrm{O}_{3}$ & 0.5 & 74.3 & - & - & $>99$ \\
\hline 7 & $\mathrm{Pt} / \mathrm{TiO}_{2}$ & 0.2 & 45.5 & - & - & $>99$ \\
\hline
\end{tabular}

a Reaction condition: $T=30^{\circ} \mathrm{C}, P=5$ bar, $m_{\text {cat }}=50 \mathrm{mg}, 1 \mathrm{mmol}$ nitrobenzene, $15 \mathrm{~mL}$ of toluene as solvent, reaction time $t=2 \mathrm{~h}$. ${ }^{\mathrm{b}}$ Identified by ICP.

$0.15418 \mathrm{~nm}$ ) at $40 \mathrm{kV}$ and $40 \mathrm{~mA}$. Elemental analysis for Pt was obtained using a PLASMA-SPEC(I) inductively coupled plasma atomic emission spectrometer (ICP). Transmission electron microscopy (TEM) images were obtained on a JEOL JEM-2010 electron microscope with an operating voltage of $200 \mathrm{kV}$. Temperature-programmed reduction (TPR) was performed using a Tianjin Xianquan TP-5079 adsorption analyzer. Before detection, the catalysts were treated in an $\mathrm{Ar}$ (99.99\%) flow at $120^{\circ} \mathrm{C}$ for $30 \mathrm{~min}$. After the sample was cooled down to $30^{\circ} \mathrm{C}$, the flowing gas was switched to $5 \mathrm{vol} \% \mathrm{H}_{2} / \mathrm{Ar}$ and the sample was heated to $800{ }^{\circ} \mathrm{C}$ with a temperature ramp rate of 10 ${ }^{\circ} \mathrm{C} / \mathrm{min}$. $\mathrm{N}_{2}$ adsorption-desorption isotherms were measured at $-196{ }^{\circ} \mathrm{C}$, using a Micromeritics ASAP 2010N analyzer. X-ray photoelectron spectroscopy (XPS) was performed on a Thermo ESCA LAB 250 system with $\mathrm{Mg} \mathrm{K}_{\alpha}$ source (1254.6 eV). Binding energies were obtained by referencing to the $C 1 s$ binding energy of carbon (peak at $284.6 \mathrm{eV}$ ). In-situ diffuse reflectance infrared Fourier transform spectroscopy (DRIFT) spectra were recorded on a Nicolet 6700 spectrometer. Among them, in-situ CO adsorption DRIFT measurement was carried out to investigate the state of Pt. The samples were pretreated in $\mathrm{N}_{2}$ flow at $100{ }^{\circ} \mathrm{C}$ for $10 \mathrm{~min}$. After the system was cooled to room temperature, a background spectrum was collected. Then the sample was exposed to $1 \mathrm{vol} \% \mathrm{CO} / \mathrm{Ar}$ flow before recording the spectra. In-situ DRIFT spectra of nitrobenzene adsorption and hydrogenation were obtained as following. Firstly, the samples were treated in $30 \mathrm{~mL} / \mathrm{min} \mathrm{N}_{2}$ flow at $100{ }^{\circ} \mathrm{C}$ for $10 \mathrm{~min}$. Then, the nitrobenzene gas was carried by $\mathrm{N}_{2}$ flow and introduced into the sample cell for adsorption. In the hydrogenation measurement, the mixture of hydrogen and the nitrobenzene gases was simultaneously introduced into the sample cell, and the spectra were in-situ recorded.

\subsection{Catalytic hydrogenation of nitroarenes}

The liquid-phase hydrogenation reaction of nitroarenes was performed in a magnetically stirred $50 \mathrm{~mL}$ stainless steel autoclave. A quantity of catalyst $(50 \mathrm{mg}$ ) was added to the autoclave containing nitroarene $(1 \mathrm{mmol})$ and toluene $(15 \mathrm{~mL})$. Then, the autoclave was flushed with 10 bar hydrogen five times. After being sealed, the autoclave was charged with $\mathrm{H}_{2}$ until 5 bar and then it was kept at $30{ }^{\circ} \mathrm{C}$. A rotation rate of $1000 \mathrm{r} / \mathrm{min}$ was used in this work, which can effectively exclude the influence of mass transfer on the reactions. The reactants and products were analyzed with a gas chromatograph (GC-112A, FID detector) equipped with an HP-5 column $(30 \mathrm{~m})$. In the recycling experiments, the solid catalyst was separated by simple decantation and directly used for the next cycle without any further treatment.

\section{Results and discussion}

The hydrogenation of nitrobenzene was carried out to screen suitable oxide supports for supported Pt catalysts. Five oxides, $\mathrm{Fe}_{2} \mathrm{O}_{3}, \mathrm{CeO}_{2}, \mathrm{Al}_{2} \mathrm{O}_{3}, \mathrm{MgO}$ and $\mathrm{TiO}_{2}$, were chosen based on their the surface acid-base properties and reducibility [36]. All the supported Pt catalysts were prepared by a colloid deposition method. For achieving the aim of low cost, the Pt contents in these catalysts were controlled at $0.1 \mathrm{wt} \%-0.5 \mathrm{wt} \%$. No Pt diffraction peaks can be observed in the XRD patterns of these supported Pt catalysts (Fig. 1 and Fig. S1). Table 1 shows the catalytic performance of these catalysts in hydrogenation of nitrobenzene. Without a catalyst or in the presence of the $\mathrm{Fe}_{2} \mathrm{O}_{3}$ support only, nearly no products can be detected (Table 1 , entries 1 and 2). Under the same reaction conditions, $\mathrm{Pt} / \mathrm{Fe}_{2} \mathrm{O}_{3}$ and $\mathrm{Pt} / \mathrm{CeO}_{2}$ exhibit obviously higher activities than $\mathrm{Pt} / \mathrm{MgO}$, $\mathrm{Pt} / \mathrm{Al}_{2} \mathrm{O}_{3}$ and $\mathrm{Pt} / \mathrm{TiO}_{2}$. Compared with $\mathrm{Pt} / \mathrm{CeO}_{2}, \mathrm{Pt} / \mathrm{Fe}_{2} \mathrm{O}_{3}$ possesses the advantage of high stability under the reaction conditions (Table 1, entries 3 and 4). It can be recovered from the reaction mixture through simple filtration, and there is no obvious change in conversion of nitrobenzene and selectivity to aniline after five successive runs (Fig. 2A). It should be noted that mass transfer can be excluded in the above tests. Because of the bulk nature of these oxides (Fig. S2), the active sites are nearly all located on the external surface of the supports. In addition, the influence of stirring rate on the catalytic performance was also investigated. The same reaction rates under 800 and $1000 \mathrm{r} / \mathrm{min}$ over the $\mathrm{Pt} / \mathrm{Fe}_{2} \mathrm{O}_{3}$ catalyst further show that mass transfer has little influence on the reaction (Fig. S3). The different activities over these catalysts should be mainly

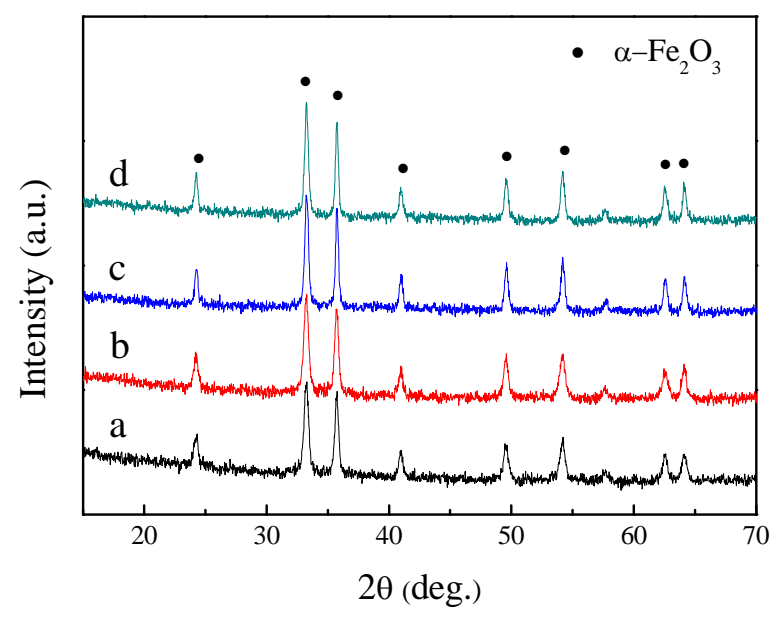

Fig. 1. XRD patterns of $0.1 \mathrm{wt} \% \mathrm{Pt} / \mathrm{Fe}_{2} \mathrm{O}_{3}(\mathrm{a}), 0.2 \mathrm{wt} \% \mathrm{Pt} / \mathrm{Fe}_{2} \mathrm{O}_{3}$ (b), 0.5 $w t \% \mathrm{Pt} / \mathrm{Fe}_{2} \mathrm{O}_{3}$ (c) and used $0.2 \mathrm{wt} \% \mathrm{Pt} / \mathrm{Fe}_{2} \mathrm{O}_{3}$ after five cycles (d). 

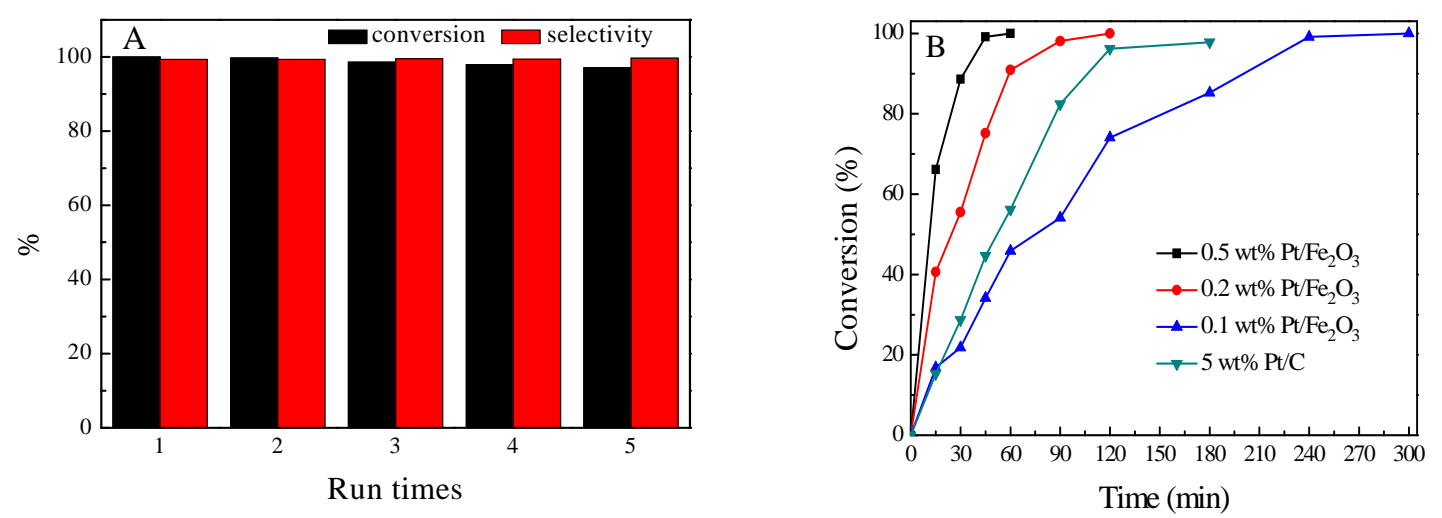

Fig. 2. (A) Recycling test over the $0.2 \mathrm{wt} \% \mathrm{Pt} / \mathrm{Fe}_{2} \mathrm{O}_{3}$ catalyst and (B) catalytic performance of $\mathrm{Pt} / \mathrm{Fe}_{2} \mathrm{O}_{3}$ with different Pt contents and commercial Pt/C catalyst. Reaction conditions: $T=30^{\circ} \mathrm{C}, P=5 \mathrm{bar}, m_{\text {cat }}=50 \mathrm{mg}, 1 \mathrm{mmol}$ nitrobenzene, $15 \mathrm{~mL}$ of toluene as solvent.

due to the surface properties of the oxide supports, which will be discussed below.

Fig. 2B shows the catalytic activities of $\mathrm{Pt} / \mathrm{Fe}_{2} \mathrm{O}_{3}$ with different Pt loadings. The conversion of nitrobenzene improves with the increase of Pt contents. According to the initial reaction rates of these catalysts, the activities are normalized by $\mathrm{Pt}$ loading, which is 2627, 3170 and 2063 mol $_{\text {conv. }} \mathrm{h}^{-1}$ molpt $^{-1}$ for $0.1 \mathrm{wt} \% \mathrm{Pt} / \mathrm{Fe}_{2} \mathrm{O}_{3}, 0.2 \mathrm{wt} \% \mathrm{Pt} / \mathrm{Fe}_{2} \mathrm{O}_{3}$ and $0.5 \mathrm{wt} \% \mathrm{Pt} / \mathrm{Fe}_{2} \mathrm{O}_{3}$, respectively. It should be noted that such high activities are obtained under quite mild reaction conditions $\left(30^{\circ} \mathrm{C}, 5\right.$ bar). Compared with the literature results under the similar reaction conditions, $\mathrm{Pt} / \mathrm{Fe}_{2} \mathrm{O}_{3}$ exhibits obvious advantage (Table S1). Compared with the commercial $\mathrm{Pt} / \mathrm{C}$ catalyst, $\mathrm{Pt} / \mathrm{Fe}_{2} \mathrm{O}_{3}$ also possesses advantage. The conversion rate of nitrobenzene over $0.5 \mathrm{wt} \% \mathrm{Pt} / \mathrm{Fe}_{2} \mathrm{O}_{3}$ and $0.2 \mathrm{wt} \% \mathrm{Pt} / \mathrm{Fe}_{2} \mathrm{O}_{3}$ is also obviously higher than $\mathrm{Pt} / \mathrm{C}$ under the same reaction conditions (Fig. 2B). It is known that the loading amount of $\mathrm{Pt}$ in the commercial $\mathrm{Pt} / \mathrm{C}$ catalyst is $5 \mathrm{wt} \%$, much higher than that of $\mathrm{Pt} / \mathrm{Fe}_{2} \mathrm{O}_{3}$.

In addition, it is found that $\mathrm{Pt} / \mathrm{Fe}_{2} \mathrm{O}_{3}$ also displayed good performance when extended to substituted nitroarenes. We mainly focus on nitroarenes with reducible groups such as $-\mathrm{C}=\mathrm{O}, \mathrm{O}=\mathrm{C}-\mathrm{O}$ and $-\mathrm{X}$ because they are with grand challenge for the application of selective hydrogenation. Table 2 shows that $\mathrm{Pt} / \mathrm{Fe}_{2} \mathrm{O}_{3}$ exhibits high selectivity to the corresponding anilines. Even for halonitrobenzene, $\mathrm{Pt} / \mathrm{Fe}_{2} \mathrm{O}_{3}$ catalyst is also with relatively high chemoselectivity. Previously, it has been reported that most Pt-based catalysts suffer from the hydrogenolysis of weak carbon-halogen bond [24]. In our case, the high chemoselectivity should be mainly due to the spatial separation of $\mathrm{H}_{2}$ dissociation and hydrogenation active sites. As for commercial Pt/C catalyst, a relatively low chemoselectivity is detected in the hydrogenation of substituted nitroarenes under the same reaction conditions (Table 2). Moreover, a decrease of chemoselectivity can also be observed over $\mathrm{Pt} / \mathrm{Fe}_{2} \mathrm{O}_{3}$ when $\mathrm{Pt}$ loading is larger than $1 \mathrm{wt} \%$, which should be due to the increase of contact possibility between Pt sites and reducible functional group.

Comparing the nitrobenzene conversion rates normalized by the Pt loading amount, it can be seen that these values are at the same order of magnitude, which should mainly ascribe to the uniform Pt nanoparticles highly dispersed on the surface of $\mathrm{Fe}_{2} \mathrm{O}_{3}$ and playing the similar role in the reaction process. It can be observed that the value over $0.5 \mathrm{wt} \% \mathrm{Pt} / \mathrm{Fe}_{2} \mathrm{O}_{3}$ is relatively low (2063 mol $_{\text {conv. }} \mathrm{h}^{-1}$ molpt $^{-1}$ ), showing that there is no linear relationship between activity and the Pt loading. This result

\section{Table 2}

Hydrogenation of different substituted nitroarenes over the $0.2 \mathrm{wt} \%$ $\mathrm{Pt} / \mathrm{Fe}_{2} \mathrm{O}_{3}$ and commercial Pt/C catalysts ${ }^{\mathrm{a}}$.

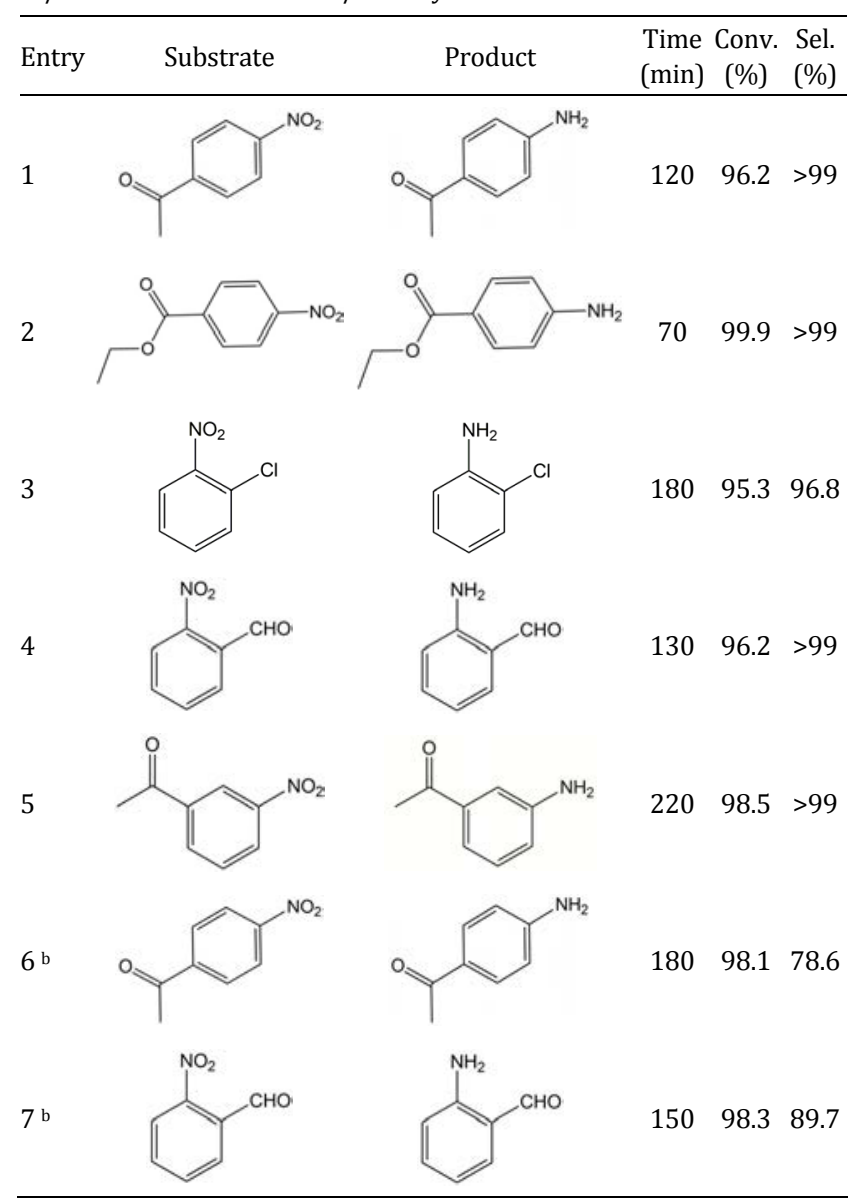

a Reaction conditions: $T=30^{\circ} \mathrm{C}, P=5 \mathrm{bar}, m_{\text {cat }}=50 \mathrm{mg}, 1 \mathrm{mmol}$ nitrobenzene, $15 \mathrm{~mL}$ of toluene as solvent. ${ }^{\mathrm{b}}$ Commercial $5 \mathrm{wt} \% \mathrm{Pt} / \mathrm{C}$ as the catalyst. 
could give strong support to our strategy that separating the hydrogenation active sites from Pt to the supports. It is known that the Pt loading of $0.5 \mathrm{wt} \%$ is also a low content value compared with many literature and the contrast sample in this case. Given that the Pt particles are the hydrogenation active sites, the average contribution of Pt would not decrease from 3170 mol $_{\text {conv. }} \mathrm{h}^{-1} \mathrm{~mol}_{\mathrm{Pt}}{ }^{-1}(0.2 \mathrm{wt} \% \mathrm{Pt})$ to $2063 \mathrm{~mol}_{\text {conv. }} \mathrm{h}^{-1} \mathrm{molpt}^{-1}(0.5$ $w t \% \mathrm{Pt}$ ). It would maintain such high conversion efficiency at least in this loading range. The results in our case show that Pt sites only serve as hydrogen dissociation centers. The hydrogenation process should occur on the surface of $\mathrm{Fe}_{2} \mathrm{O}_{3}$ supports. According to above results, a reaction mechanism concerning $\mathrm{H}_{2}$ dissociation, nitroarene adsorption and hydrogenation is proposed (Scheme 1). The $\mathrm{Fe}_{2} \mathrm{O}_{3}$ support provides adsorption sites for the nitroarenes and should also function as the reaction area for the hydrogenation.

To verify this hypothesis, a series of characterizations were carried out to detect the physicochemical properties of $\mathrm{Pt} / \mathrm{Fe}_{2} \mathrm{O}_{3}$ and in-situ reaction process of nitroarene hydrogenation over this catalyst. XRD patterns (Fig. 1) show that only diffraction peaks assigned to $\alpha-\mathrm{Fe}_{2} \mathrm{O}_{3}$ phase could be observed on the patterns of both samples with different Pt contents and the one after five cycles. It shows that $\alpha-\mathrm{Fe}_{2} \mathrm{O}_{3}$ possesses a relatively high stability. Both the reducibility of Pt colloids in the preparation process and the strong reduction atmosphere in the reaction process have little influence on the phase structure of $\alpha-\mathrm{Fe}_{2} \mathrm{O}_{3}$. No diffraction peaks assigned to Pt can be observed, suggesting that $\mathrm{Pt}$ nanoparticles are highly dispersed on the surface of $\alpha-\mathrm{Fe}_{2} \mathrm{O}_{3}$.

TEM images further confirm the above results. Fig. $3 \mathrm{~b}$ and $3 c$ shows that almost all $\mathrm{Pt}$ particles in the $\mathrm{Pt} / \mathrm{Fe}_{2} \mathrm{O}_{3}$ catalyst are consistent with the size of Pt particles in the colloids (Fig. 3a). The size of 3-4 nm is the most probable distribution of these particles. It should be noted that Pt nanoparticles are highly dispersed on the surface of the $\mathrm{Fe}_{2} \mathrm{O}_{3}$ support, which might be correlated with the low loading amount. The shortest distance between two Pt nanoparticles is about $12 \mathrm{~nm}$ in the detected

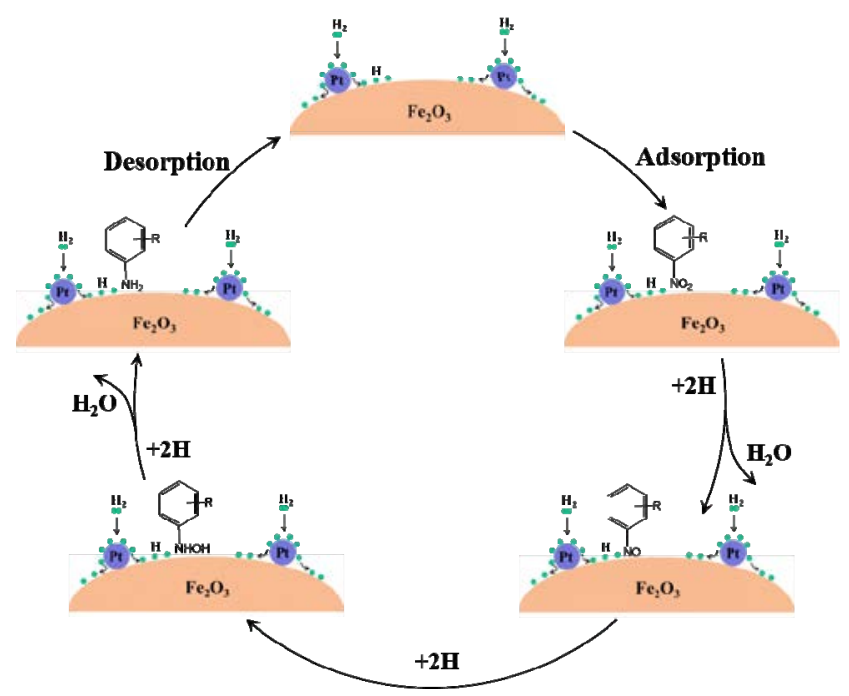

Scheme 1. Proposed reaction mechanism of $\mathrm{H}_{2}$ dissociation, adsorption and hydrogenation of nitroarenes on the $\mathrm{Pt} / \mathrm{Fe}_{2} \mathrm{O}_{3}$ catalyst. region. As for the spatial separation of the active sites, enough reaction area is needed, which could effectively reduce the contact possibility between the reducible groups of nitroarenes and Pt sites. Considering the largest molecule in the reactants is about $6 \AA$, it can be speculated that $\mathrm{Pt} / \mathrm{Fe}_{2} \mathrm{O}_{3}$ provides enough spaces to achieve the spatial separation of $\mathrm{H}_{2}$ dissociation and hydrogenation active sites. Besides, the TEM images of the sample after five cycles are also shown in Fig. 3. Both the sizes and dispersion states of Pt are almost the same as that of the fresh one. No particle aggregation can be observed, suggesting that Pt nanoparticles possess a high stability during the reaction process.

Pt $4 f$ XPS was measured to analyze the surface chemical state of Pt nanoparticles (Fig. 4). Because of the detection limit, Pt signals in low Pt-content samples are hard to detect, so 0.5 wt $\% \mathrm{Pt} / \mathrm{Fe}_{2} \mathrm{O}_{3}$ was used as the representative sample for testing. Two main peaks centered at about 71.5 and $74.6 \mathrm{eV}$ can be observed, which are corresponding to the spin-orbit split doublet of Pt $4 f_{7 / 2}$ and Pt $4 f_{5 / 2}$, respectively [33,37-39]. The binding energy of this original peak center is consistent with the $\mathrm{Pt}^{0}$ electron binding energy. Although the spectra still could be deconvoluted into the components of metal $\mathrm{Pt}\left(\mathrm{Pt}^{0}\right)$ and oxide states $\mathrm{Pt}\left(\mathrm{Pt}^{2+}\right)$, the amount of oxide states $\mathrm{Pt}\left(\mathrm{Pt}^{2+}\right)$ is quite limited. Metallic Pt should be the absolutely predominant one in the sample.

Furthermore, in-situ DRIFT spectra of adsorbed CO at room temperature were also recorded over the samples of $0.1 \mathrm{wt} \%$ $\mathrm{Pt} / \mathrm{Fe}_{2} \mathrm{O}_{3}, 0.2 \mathrm{wt} \% \mathrm{Pt} / \mathrm{Fe}_{2} \mathrm{O}_{3}$ and $0.5 \mathrm{wt} \% \mathrm{Pt} / \mathrm{Fe}_{2} \mathrm{O}_{3}$ to confirm the chemical state of Pt. It is known that $v_{\mathrm{co}}>2100 \mathrm{~cm}^{-1}$ is assigned to the linear adsorption of $\mathrm{CO}$ on oxide states Pt, while $v_{\text {co }}<2100 \mathrm{~cm}^{-1}$ is ascribed to $\mathrm{CO}$ adsorbed on metallic Pt $[40,41]$. Fig. 5 shows that a relatively strong band at $2085 \mathrm{~cm}^{-1}$ appears in all three samples, which can be ascribed to $\mathrm{CO}$ adsorbed on metallic Pt. This result confirms that Pt mainly presents as metallic state in $\mathrm{Pt} / \mathrm{Fe}_{2} \mathrm{O}_{3}$, and a small amount of $\mathrm{Pt}^{2+}$ detected by Pt $4 f$ XPS should be located at the interface between Pt nanoparticles and supports, which can be reflected from the shoulder peak of $\mathrm{CO}$ adsorption. This metallic Pt possesses strong $\mathrm{H}_{2}$ dissociation ability. $\mathrm{H}_{2}$-TPR profiles show that the reduction peaks corresponding to $\mathrm{Fe}^{3+}$ to $\mathrm{Fe}^{2+}$ shift signifi-

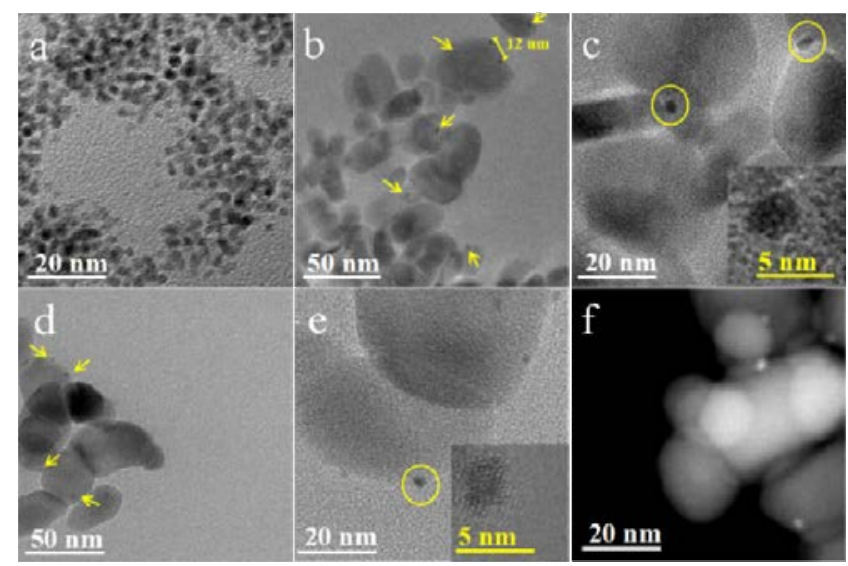

Fig. 3. TEM images of Pt colloids (a), $0.2 \mathrm{wt} \% \mathrm{Pt} / \mathrm{Fe}_{2} \mathrm{O}_{3}$ (b and c) and used $0.2 \mathrm{wt} \% \mathrm{Pt} / \mathrm{Fe}_{2} \mathrm{O}_{3}$ after five cycles (d, e and f). 

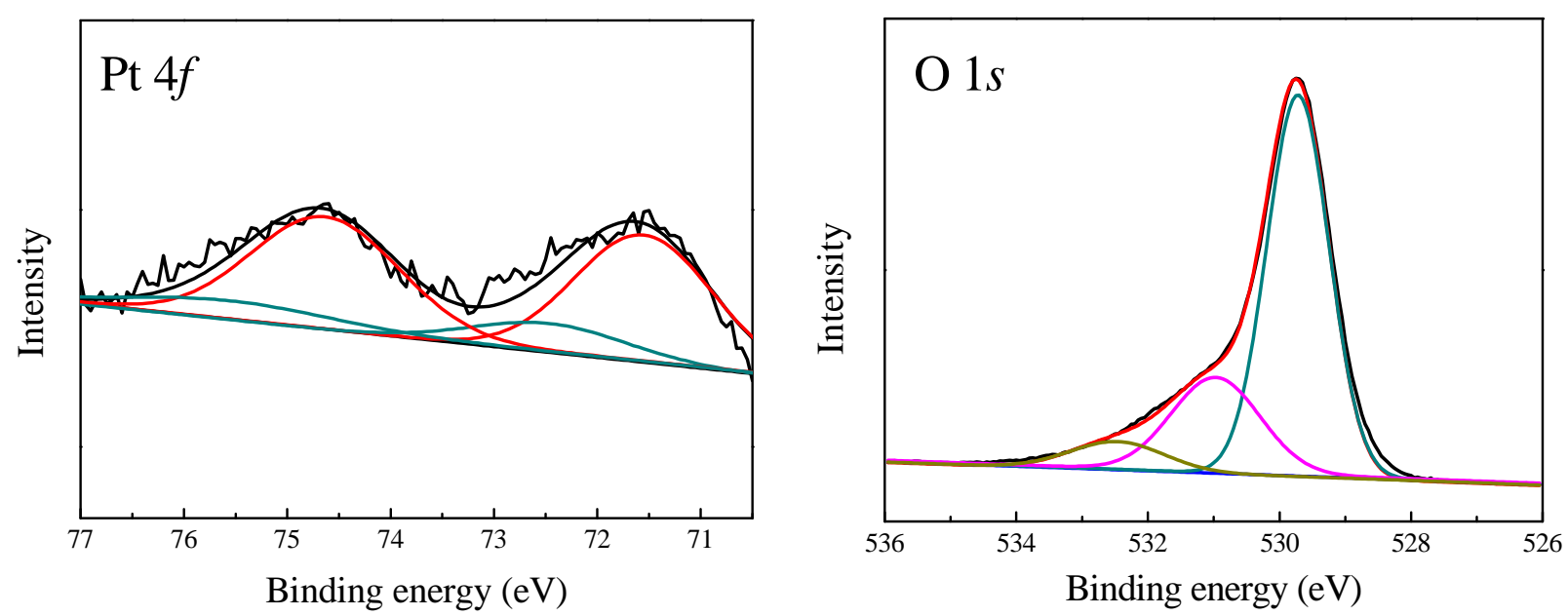

Fig. 4. $\mathrm{Pt} 4 f$ and $\mathrm{O} 1 s \mathrm{XPS}$ spectra of $0.5 \mathrm{wt} \% \mathrm{Pt} / \mathrm{Fe}_{2} \mathrm{O}_{3}$.

cantly to the relatively low temperature in the presence of $\mathrm{Pt}$ nanoparticles (Fig. 6). It decreases at least $120{ }^{\circ} \mathrm{C}$ compared with that of pure $\mathrm{Fe}_{2} \mathrm{O}_{3}$ support. Increasing the Pt contents could further decrease the reduction temperature. In addition, the low reduction temperature and narrow reduction peak could also show that $\mathrm{Fe}_{2} \mathrm{O}_{3}$ support possesses excellent hydrogen spillover capability. It could facilitate the diffusion of hydrogen on the surface of $\mathrm{Fe}_{2} \mathrm{O}_{3}$. In our case, the strong $\mathrm{H}_{2}$ dissociation ability of Pt nanoparticles and hydrogen spillover capability of $\mathrm{Fe}_{2} \mathrm{O}_{3}$ support should be two important factors that catalyze the hydrogenation reaction under mild conditions (30 ${ }^{\circ} \mathrm{C}, 5$ bar).

For understanding the adsorption behavior and hydrogenation of nitroarenes over the $\mathrm{Pt} / \mathrm{Fe}_{2} \mathrm{O}_{3}$ catalyst, in-situ DRIFT measurements were carried out. Nitrobenzene is introduced by a $\mathrm{N}_{2}$ flow to the $\mathrm{Fe}_{2} \mathrm{O}_{3}$ support and $0.2 \mathrm{wt} \% \mathrm{Pt} / \mathrm{Fe}_{2} \mathrm{O}_{3}$. Two bands appeared at 1531 and $1350 \mathrm{~cm}^{-1}$ could be attributed to asymmetric stretching and symmetric stretching vibrations of the nitro group, respectively [28]. There is no difference between $\mathrm{Fe}_{2} \mathrm{O}_{3}$ support and $\mathrm{Pt} / \mathrm{Fe}_{2} \mathrm{O}_{3}$ (Fig. 7a and 7c), suggesting

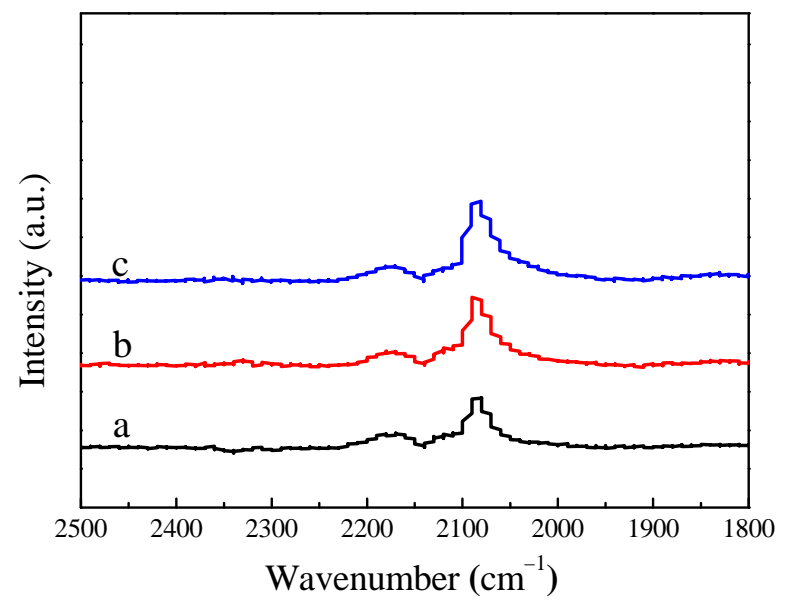

Fig. 5. In-situ DRIFT spectra of $\mathrm{CO}$ adsorbed on $0.1 \mathrm{wt} \% \mathrm{Pt} / \mathrm{Fe}_{2} \mathrm{O}_{3}$ (a), $0.2 \mathrm{wt} \% \mathrm{Pt} / \mathrm{Fe}_{2} \mathrm{O}_{3}$ (b) and $0.5 \mathrm{wt} \% \mathrm{Pt} / \mathrm{Fe}_{2} \mathrm{O}_{3}$ (c). that the nitro group mainly adsorbed on the surface of $\mathrm{Fe}_{2} \mathrm{O}_{3}$ support. Upon introducing $\mathrm{H}_{2}$ to $0.2 \mathrm{wt} \% \mathrm{Pt} / \mathrm{Fe}_{2} \mathrm{O}_{3}$, a new broad band can be observed at $1589-1620 \mathrm{~cm}^{-1}$ (Fig. $7 \mathrm{~d}$ ), which is attributed to the vibrations of $-\mathrm{NO}$ and $-\mathrm{NH}_{2}$ species $[28,42,43]$. This suggests that hydrogenation of nitrobenzene occurs over $0.2 \mathrm{wt} \% \mathrm{Pt} / \mathrm{Fe}_{2} \mathrm{O}_{3}$. In contrast, when $\mathrm{H}_{2}$ is introduced to the $\mathrm{Fe}_{2} \mathrm{O}_{3}$ support, no signal assigned to $-\mathrm{NH}_{2}$ species can be observed (Fig. 7b). This is mainly due to the lack of $\mathrm{H}_{2}$ dissociation sites on the $\mathrm{Fe}_{2} \mathrm{O}_{3}$ support.

The strong nitrobenzene adsorption behavior for $\mathrm{Fe}_{2} \mathrm{O}_{3}$ should origin from the presence of oxygen vacancies. The $01 \mathrm{~s}$ XPS spectrum (Fig. 4) indicates that a large amount of oxygen vacancy $(531 \mathrm{eV})$ is present on the surface of $\mathrm{Pt} / \mathrm{Fe}_{2} \mathrm{O}_{3}[44,45]$. These oxygen vacancies are electron-rich sites, which could have a relatively strong interaction with nitro groups (strong electron-withdrawing group). Correspondingly, a relatively broad Fe $2 p$ XPS peak (711 and $724.3 \mathrm{eV}$ ) can be observed (Fig. S4). It shows that most of iron species on the surface of the samples are present as a valence of +3 , combining with a small amount of iron species with a valence of $+2[10,46]$. This property should facilitate both the reactant adsorption and the hy-

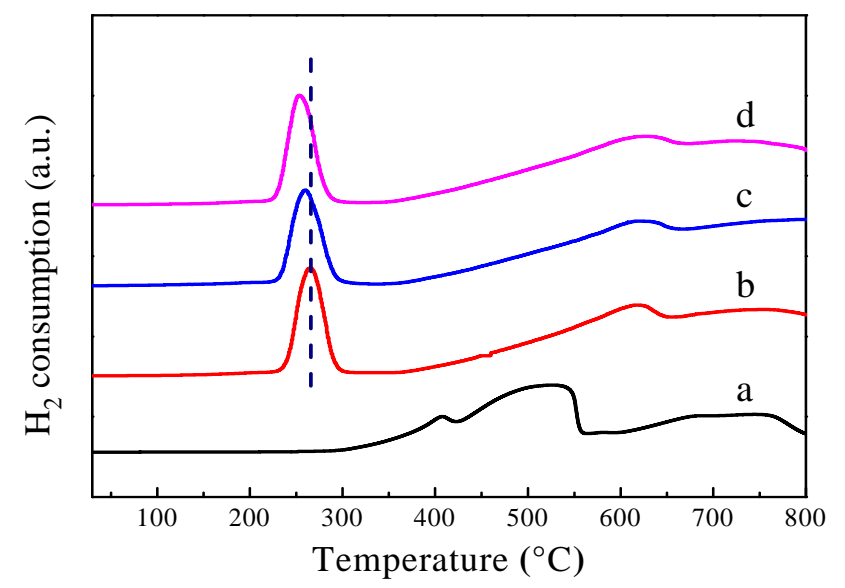

Fig. 6. $\mathrm{H}_{2}$-TPR profiles of $\mathrm{Fe}_{2} \mathrm{O}_{3}(\mathrm{a}), 0.1 \mathrm{wt} \% \mathrm{Pt} / \mathrm{Fe}_{2} \mathrm{O}_{3}$ (b), $0.2 \mathrm{wt} \%$ $\mathrm{Pt} / \mathrm{Fe}_{2} \mathrm{O}_{3}$ (c) and $0.5 \mathrm{wt} \% \mathrm{Pt} / \mathrm{Fe}_{2} \mathrm{O}_{3}$ (d). 


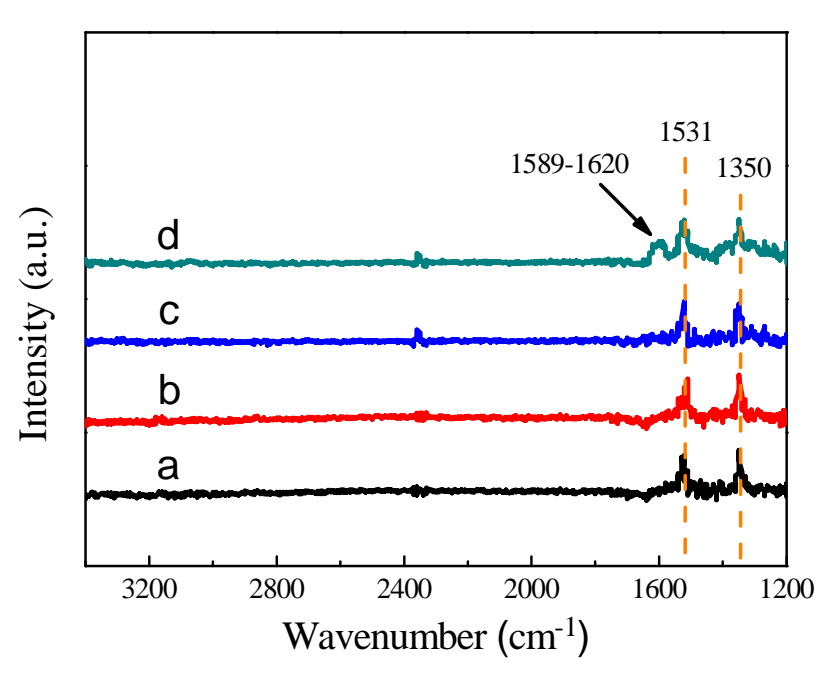

Fig. 7. In-situ DRIFT spectra of nitrobenzene adsorption over $\mathrm{Fe}_{2} \mathrm{O}_{3}$ (a) and $0.2 \mathrm{wt} \% \mathrm{Pt} / \mathrm{Fe}_{2} \mathrm{O}_{3}$ (c); co-presence of nitrobenzene and $\mathrm{H}_{2}: \mathrm{Fe}_{2} \mathrm{O}_{3}$ (b) and $0.2 \mathrm{wt} \% \mathrm{Pt} / \mathrm{Fe}_{2} \mathrm{O}_{3}(\mathrm{~d})$.

drogen spillover.

It should be noted that the high stability of $\alpha-\mathrm{Fe}_{2} \mathrm{O}_{3}$ under the reduction condition is also a critical factor for $\mathrm{Pt} / \mathrm{Fe}_{2} \mathrm{O}_{3}$ to become an excellent catalyst. We had ever detected the performance of ferrihydrite $\left(\mathrm{Fe}\left(\mathrm{OH}, \mathrm{H}_{2} \mathrm{O}\right)\right.$ and composite iron oxides co-presence of $\left(\mathrm{Fe}\left(\mathrm{OH}, \mathrm{H}_{2} \mathrm{O}\right)\right.$ and $\alpha-\mathrm{Fe}_{2} \mathrm{O}_{3}$ (Fig. S5). It is well known that the presence of water could accelerate the diffusion of hydrogen atoms across solid oxide surfaces. Although the catalysts prepared with above two oxides exhibit a little higher initial activity than $\alpha-\mathrm{Fe}_{2} \mathrm{O}_{3}$ (Fig. S6), their poor performance in the following reaction cycles shows that they cannot become efficient catalysts (Fig. S7). As for the support of $\alpha-\mathrm{Fe}_{2} \mathrm{O}_{3}$, it exhibits not only relatively high activity but also high stability in the hydrogenation of nitroarenes.

Combined with the catalytic tests and characterization results, it can be confirmed that the supports play an important role in the reaction process. The catalyst performance directly correlates with their capability of reactant adsorption and hydrogen spillover. Reducible oxides have higher capability of hydrogen spillover than irreducible oxide supports, which reflects on not only the spillover speed but also the migrated distance [30]. It should be the main reason that $\mathrm{Al}_{2} \mathrm{O}_{3}$ - and MgO-supported Pt catalysts exhibit low activities. The stability of the supports under the reduction condition should also be concerned. The poor recyclability of $\mathrm{CeO}_{2}$ and ferrihydrite supported samples should be mainly due to the stability of the oxide support in the presence of $\mathrm{H}_{2}$. Actually, both $\mathrm{CeO}_{2}$ and ferrihydrite have higher reducibility than $\alpha-\mathrm{Fe}_{2} \mathrm{O}_{3}$ because of the high activity of surface oxygen species, but these active species are easily damaged in the strong reduction atmosphere of $\mathrm{H}_{2}$.

In addition, the adsorption behavior of the supports is another important factor that affects the catalytic performance of these catalysts. It is directly affected by the surface electronic properties of the supports. Some literature has reported that modifying the catalysts with vanadium salts or organic thiol compounds could effectively tune the adsorption and desorption behavior of the catalysts $[19,20]$. The role of vanadium salts is to avoid accumulation of hazardous aromatic hydroxylamines, while organic thiol compounds could avoid the flat adsorption of nitroarenes via the benzene ring. Flat adsorption would cause a simultaneous exposure of the reducible groups toward the active sites. In our case, the suitable surface chemical state of $\alpha-\mathrm{Fe}_{2} \mathrm{O}_{3}$ facilitates the adsorption of nitro group of nitroarenes. The unique properties of $\alpha-\mathrm{Fe}_{2} \mathrm{O}_{3}$ realize its high performance cooperated with Pt nanoparticles for chemoselective hydrogenation of niroarenes.

\section{Conclusions}

$\mathrm{Pt} / \mathrm{Fe}_{2} \mathrm{O}_{3}$ prepared by a colloidal deposition method exhibits high activity and chemoselectivity in hydrogenation of nitroarenes. Uniform Pt nanoparticles, mainly present as metallic $\mathrm{Pt}^{0}$, highly disperse on the surface of the $\alpha-\mathrm{Fe}_{2} \mathrm{O}_{3}$ support, facilitating the dissociation of $\mathrm{H}_{2}$. Stable $\alpha-\mathrm{Fe}_{2} \mathrm{O}_{3}$ support possesses the ability of selective adsorption of nitro group and diffusion of hydrogen, providing the active sites for hydrogenation of nitroarenes. The low contents of Pt lead to spatial separation of the active sites for $\mathrm{H}_{2}$ dissociation and hydrogenation, which effectively reduce the contact possibility between Pt and nitroarenes, avoiding the undesirable hydrogenation of other reducible functional groups.

\section{References}

[1] E. Schmidt, A. Vargas, T. Mallat, A. Baiker, J. Am. Chem. Soc., 2009, 131, 12358-12367.

[2] W. Y. Cui, D. Xue, N. D. Tan, B. Zheng, M. J. Jia, W. X. Zhang, Chin. J. Catal., 2018, 39, 1534-1542.

[3] J. J. Liu, S. H. Zou, J. C. Wu, H. Kobayashi, H. T. Zhao, J. Fan, Chin. J. Catal., 2018, 39, 1081-1089.

[4] B. Zheng, S. J. Wu, X. W. Yang, M. J. Jia, W. X. Zhang, G. Liu, ACS. Appl. Mater. Inter., 2016, 8, 26683-26689.

[5] P. P. Ye, A. J. Gellman, J. Am. Chem. Soc., 2008, 130, 8518-8526.

[6] G. C. da Silva, M. R. Fernandes, E. A. Ticianelli, ACS. Catal., 2018, 8, 2081-2092.

[7] Z. J. Chen, J. Y. Chen, Y. W. Li, Chin. J. Catal, 2017, 38, 1108-1126.

[8] S. Anantharaj, P. E. Karthik, B. Subramanian, S. Kundu, ACS. Catal., 2016, 6, 4660-4672.

[9] Y. L. Sui, S. B. Liu, T. F. Li, Q. X. Liu, T. Jiang, Y. F. Guo, J. L. Luo, J. Catal., 2017, 353, 250-255.

[10] L. L. Geng, M. Zhang, W. X. Zhang, M. J. Jia, W. F. Yan, G. Liu, Catal. Sci. Technol., 2015, 5, 3097-3102.

[11] R. V. Jagadeesh, A. E. Surkus, H. Junge, M-M. Pohl, J. Radnik, J. Rabeah, H. Huan, V. Schünemann, A. Brückner, M. Beller, Science, 2013, 342, 1073 - 1076.

[12] Y. J. Shu, T. Chen, H. C. Chan, L. F. Xie, Q. S. Gao, Chem - Asian. J., 2018, 13, 3737-3744.

[13] Q. M. Hu, S. Wang, Z. Gao, Y. Q. Li, Q. Zhang, Q. Xiang, Y. Qin, Appl. Catal. B: Environ., 2017, 218, 591-599.

[14] M. W. Zhu, B. Huang, Q. Shao, Y. C. Pi, Y. Qian, X. Q. Huang, ChemCatChem., 2018, 10, 3214-3218.

[15] W. Shi, B. S. Zhang, Y. M. Lin, Q. Wang, Q. Zhang, D. S. Su, ACS. Catal., 


\section{Graphical Abstract}

Chin. J. Catal., 2019, 40: 214-222 doi: S1872-2067(19)63276-6

Synergism of Pt nanoparticles and iron oxide support for chemoselective hydrogenation of nitroarenes under mild conditions

Pei Jing, Tao Gan, Hui Qi, Bin Zheng, Xuefeng Chu, Guiyang Yu, Wenfu Yan, Yongcun Zou, Wenxiang Zhang *, Gang Liu * Jilin University; The Second Hospital of Jilin University; Jilin Jianzhu University

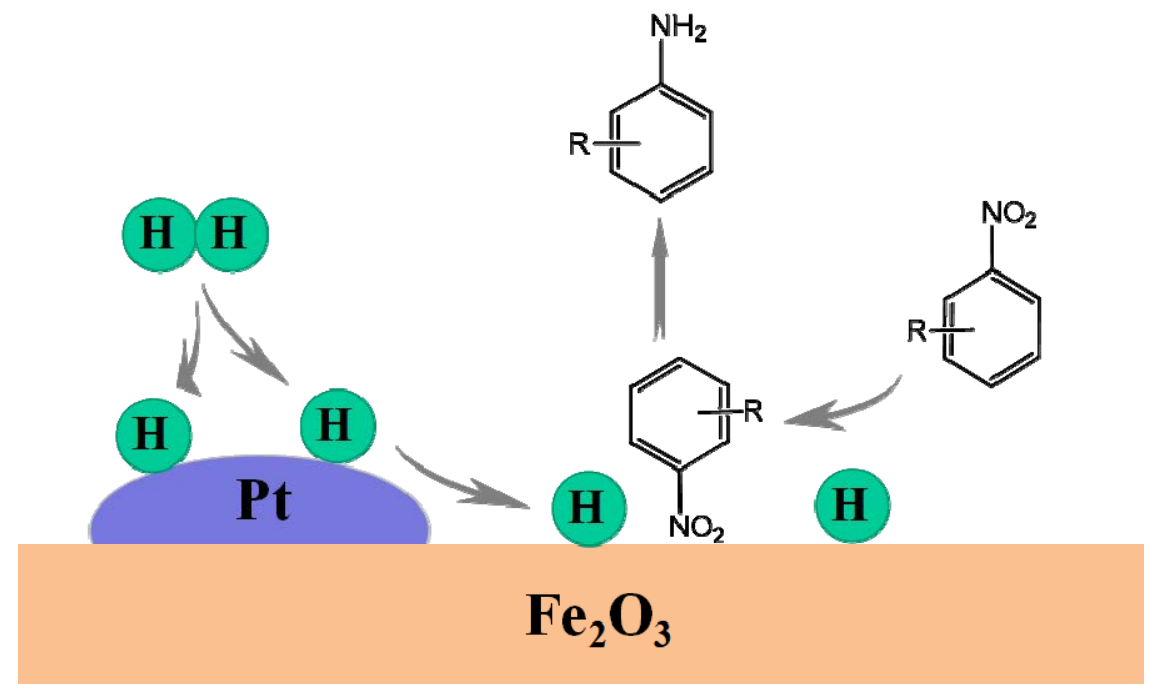

$\mathrm{Pt} / \alpha-\mathrm{Fe}_{2} \mathrm{O}_{3}$ with ultralow Pt loading amount could spatially separate the active sites for $\mathrm{H}_{2}$ dissociation and hydrogenation, leading to a high chemoselectivity for hydrogenation of nitroarenes under mild reaction conditions.

2016, 6, 7844-7854.

[16] P. Lara, K. Philippot, Catal. Sci. Technol., 2014, 4, 2445-2465.

[17] G. Vilé, D. Albani, N. Almora-Barrios, N. López, J. Pérez-Ramírez, ChemCatChem., 2016, 8, 21-33.

[18] J. Wang, Y. J. Zhang, J. Y. Diao, J. Y. Zhang, H. Y. Liu, D. S.Su, Chin. J. Catal., 2018, 39, 79-87.

[19] K. Möbus, D. Wolf, H. Benischke, U. Dittmeier, K. Simon, U. Packruhn, R. Jantke, S. Weidlich, C. Weber, B. S. Chen, Top. Catal., 2010, 53, 1126-1131.

[20] M. Makosch, W-I. Lin, V. Bumbálek, J. Sá, J. W. Medlin, K. Hungerbühler, J. A. van Bokhoven, ACS. Catal., 2012, 2, 2079-2081.

[21] K-i. Shimizu, Y. Miyamoto, A. Satsuma, J. Catal., 2010, 270, 86-94.

[22] K-i. Shimizu, Y. Miyamoto, T. Kawasaki, T. Tanji, Y. Tai, A. Satsuma, J. Phys. Chem. C., 2009, 113, 17803-17810.

[23] T. Mitsudome, Y. Mikami, M. Matoba, T. Mizugaki, K. Jitsukawa, K. Kaneda, Angew. Chem. Int. Ed., 2012, 51, 136-139.

[24] H. S. Wei, X. Y. Liu, A. Q. Wang, L. L. Zhang, B. T. Qiao, X. F. Yang, Y. Q. Huang, S. Miao, J. Y. Liu, T. Zhang, Nat. Commun., 2014, 5, 5634-5641.

[25] A. Corma, P. Serna, P. Concepcion, J. J. Calvino, J. Am. Chem. Soc., 2008, 130, 8748-8753.

[26] S. Zhang, C. R. Chang, Z. Q. Huang, J. Li, Z. M. Wu, Y. Y. Ma, Z. Y. Zhang, Y. Wang, Y. Q. Qu, J. Am. Chem. Soc., 2016, 138, 2629-2637.

[27] L. Wang, E. J. Guan, J. Zhang, J. H. Yang, Y. H. Zhu, Y. Han, M. Yang, C. Cen, G. Fu, B. C. Gates, F. S. Xiao, Nat. Commun., 2018, 9, 1362-1369.

[28] H. S. Wei, Y. J. Ren, A. Q. Wang, X. Y. Liu, X. Liu, L. L. Zhang, S. Miao,
L. Li, J. Y. Liu, J. H. Wang, G. F. Wang, D. S. Su, T. Zhang, Chem. Sci., 2017, 8, 5126-5131.

[29] B. Zhang, H. Asakura, J. Zhang, J. G. Zhang, S. De, N. Yan, Angew. Chem. Int. Ed., 2016, 55, 8319-8323.

[30] W. Karim, C. Spreafico, A. Kleibert, J. Gobrecht, J. VandeVondele, Y. Ekinci, J. A. van Bokhoven, Nature, 2017, 541, 68-71.

[31] L. R. Merte, G. Peng, R. Bechstein, F. Rieboldt, C. A. Farberow, L. C. Grabow, W. Kudernatsch, S. Wendt, E. Laegsgaard, M. Mavrikakis, F. Besenbacher, Science, 2012, 336, 889-893.

[32] R. Prins, Chem. Rev., 2012, 112, 2714-2738.

[33] B. Zheng, G. Liu, L. L. Geng, J. Y. Cui, S. J. Wu, P. Wu, M. J. Jia, W. F. Yan, W. X. Zhang, Catal. Sci. Technol., 2016, 6, 1546-1554.

[34] A. Corma, P. Serna, H. Garcia, J. Am. Chem. Soc., 2007, 129, 6358-6359.

[35] M. Boronat, P. Concepcion, A. Corma, S. Gonzalez, F. Illas, P. Serna, J. Am. Chem. Soc., 2007, 129, 16230-16237.

[36] J. L. Song, G. Y. Yu, X. Li, X. W. Yang, W. X. Zhang, W. F. Yan, G. Liu, Chin. J. Catal., 2018, 39, 309-318.

[37] L. Q. Liu, F. Zhou, L. G. Wang, X. J. Qi, F. Shi, Y. Q. Deng, J. Catal., 2010, 274, 1-10.

[38] Z. Z. Yang, N. Zhang, Y. Cao, M. C. Gong, M. Zhao, Y. Q. Chen, Catal. Sci. Technol., 2014, 4, 3032-3043.

[39] R. Ahmadi, M. K. Amini, J. C. Bennett, J. Catal., 2012, 292, 81-89.

[40] E. Ivanova, M. Mihaylov, F. Thibault-Starzyk, M. Daturi, K. Hadjiivanov, J. Mol. Catal. A, 2007, 274, 179-184.

[41] S. Shen, X. L. Wang, Q. Ding, S. Q. Jin, Z. C. Feng, C. Li, Chin. J. Catal., 2014, 35, 1900-1906.

[42] G. Richner, J. A. van Bokhoven, Y. M. Neuhold, M. Makosch, K. 
Hungerbuhler, Phys. Chem. Chem. Phys., 2011, 13, 12463-12471.

[43] S. Meijers, V. Ponec, J. Catal., 1996, 160, 1-9.

[44] D. Flak, Q. Chen, B. S. Mun, Z. Liu, M. Rękas, A. Braun, Appl. Surf. Sci,, 2018, 455, 1019-1028.
[45] S. Sultana, S. Mansingh, K. M. Parida, J. Mater. Chem. A., 2018, 6, 11377-11389.

[46] L. L. Geng, J. L. Song, B. Zheng, S. J. Wu, W. X. Zhang, M. J. Jia, G. Liu, Chin. J. Catal., 2016, 37, 1451-1460.

\title{
铂纳米粒子与氧化铁载体协同作用促进芳香硝基化合物温和条件下选择加氢
}

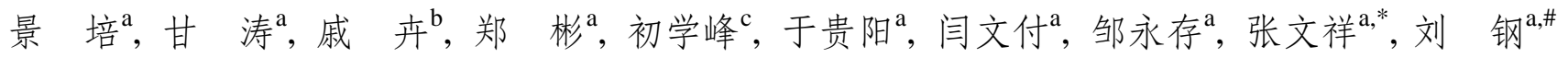 \\ a吉林大学化学学院, 无机合成与制备化学国家重点实验室, 吉林长春130012

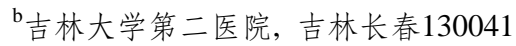 \\ c 吉林建筑大学电气与电子信息工程学院, 吉林省建筑电气综合节能重点实验室, 吉林长春130041
}

摘要: 负载型 $\mathrm{Pt}$ 基催化剂是一类重要的工业催化剂, 在很多还原和氧化反应中都表现出很高的催化活性, 但高昂的价格一 直制约着Pt基催化剂的大规模应用. 另外, Pt活性位点对有机化合物不同基团的区分性差, 通常造成目的产物的选择性较 低. 以人们熟知的芳香硝基化合物加氢为例, 当有其它易还原基团如 $C=C 、 C=O 、-X$ 等存在时, 在硝基加氢的同时, 这些基 团也不同程度地被还原. 在已报道的工作中, 通过合理设计 Pt活性中心结构、改善Pt周围环境以及在反应中添加无机盐或 有机化合物等方法, 芳香硝基化合物加氢的选择性获得大幅提升, 但催化剂活性对Pt负载量的依赖性仍然很高, 降低催化 剂中的Pt活性位数量会显著降低催化剂活性. 此外, Pt纳米粒子在反应过程中的聚集以及氧化物载体在强还原气氛下的性 能变化等对催化剂的稳定性产生很大影响.

本文工作中我们尝试发挥载体在反应中的作用, 实现氢解离和反应物加氢活性中心在空间上分离, 从而降低Pt的负载 量. 工作思路主要是基于氢溢流的基本原理, 其难点在于高效氢解离活性中心的设计和载体的选择, 后者需满足活泼氢物 种的输运和硝基基团的有效吸附. 为了实现上述目标, 本文采用胶体法制备了 $3-4 \mathrm{~nm}$ 的Pt粒子, 该方法可以有效地控制 $\mathrm{Pt}$ 纳米粒子的尺寸以及在载体上的分散状态, 从而形成大量的 $\mathrm{Pt}^{0}$ 活性位, 实现高效氢解离. 在充分考虑载体的氧化还原性和 表面碱性质(给电子能力)的基础上, 我们篮选了多种氧化物作为载体. 反应结果显示, $\mathrm{Pt} / \alpha-\mathrm{Fe}_{2} \mathrm{O}_{3}$ 在 $\mathrm{Pt}$ 负载量仅为 $0.2 \mathrm{wt} \%$ 时 即表现出很高的芳香硝基化合物加氢催化活性和选择性, 并且该反应可在相当温和的条件 $\left(30^{\circ} \mathrm{C}, 5 \mathrm{bar} \mathrm{H}_{2}\right)$ 下进行. 在经过 多次循环反应后, $\mathrm{P}$ 纳米粒子的尺寸、分散状态以及 $\alpha-\mathrm{Fe}_{2} \mathrm{O}_{3}$ 载体的物相等均未发生变化, 催化剂表现出很高的稳定性.

Pt纳米粒子的高效氢解离能力是催化剂实现高活性的重要因素之一, 而 $\alpha-\mathrm{Fe}_{2} \mathrm{O}_{3}$ 的表面性质也同样发挥了重要作用, 其 表面一定数量的氧空位具有较强的给电子能力, 可以与具有较强吸电子能力的硝基基团作用, 实现反应物的高效吸附; 载 体表面适当的氧化还原性有利于活泼氢的输运, 在与Pt纳米粒子的协同作用下实现了温和条件下芳香硝基化合物的选择 性加氢. 本工作显著降低了 $\mathrm{Pt}$ 的使用量, 实现了非常温和条件下的稳定、高效加氢, 可为低成本 $\mathrm{Pt}$ 基催化剂的设计提供借鉴. 关键词：负载型铂基催化剂; 氧化铁; 芳香硝基化合物加氢; 选择性; 贵金属催化

收稿日期: 2018-12-18. 接受日期: 2018-12-20. 出版日期: 2019-02-05.

*通讯联系人. 电话: (0431)85155390; 传真: (0431)88499140; 电子信箱: zhwenx@jlu.edu.cn

\#通讯联系人. 电话: (0431)85155390; 传真: (0431)88499140; 电子信箱: Igang@jlu.edu.cn

基金来源：国家自然科学基金(21473073，21473074); 吉林省科技发展计划(20170101171JC, 20180201068SF); 吉林省教育厅“十 三五”科学技术研究项目(2016403); 无机合成和制备化学国家重点实验室开放项目(201703).

本文的电子版全文由Elsevier出版社在ScienceDirect上出版(http://www.sciencedirect.com/science/journal/18722067). 